\title{
FRAGILIDADE DO PLURALISMO DEMOCRÁTICO, UMA ABORDAGEM A PARTIR DE TOCQUEVILLE
}

\section{FRAGILITY OF DEMOCRATIC PLURALISM, AN APPROACH FROM TOCQUEVILLE}

\author{
Helena Esser dos Reis ${ }^{1}$
}

\section{RESUMO}

Desde a concepção iluminista de tolerância, a desconfiança em relação às certezas irretorquíveis e o acolhimento do outro passaram a orientar relações sociais e políticas pluralistas e democráticas, tendo em vista a proteção da pessoa e a promoção da justiça e da paz. Contudo, há uma permanente tensão entre reivindicações de direitos e conquistas garantidas, que se enraíza em questões sociais e culturais associadas à noção do tolerável ou do que pode ser admitido como equiparável, simétrico e, portanto respeitável, apesar de diferente. No âmbito deste artigo, partindo de uma concepção de tolerância religiosa como origem do pluralismo democrático, quer-se investigar, a tênue fronteira que separa o aceitável do não aceitável, o cidadão daquele que, apesar de se assim chamado, não pode exercer sua cidadania, sua voz não é ouvida, não participa. A discussão acerca da fragilidade do pluralismo democrático será feita a partir da investigação das obras e textos de Alexis de Tocqueville. A análise de seu pensamento é bastante importante porque, tendo caracterizado a democracia pela confluência entre condições sociais de igualdade e condições políticas de liberdade, quando visitou os Estados Unidos em 1830 explicita, com certa ironia, existência de democracia exclusivamente entre os "anglo-americanos". Narrando a situação social e política vivida pelos negros e indígenas que habitavam a América do Norte, repudia e denuncia a exclusão e a violência às quais estavam submetidos. Embora Tocqueville afirme que a exclusão de negros e indígenas da democracia norte-americana seja uma ameaça à própria democracia, sua concepção parece admitir a integração pela assimilação da cultura democrático-europeia por parte dos negros e indígenas. A tensão existente entre "anglo-americanos", negros e indígenas será objeto de investigação, a fim de discutir a possibilidade de inclusão do outro e os limites do pluralismo democrático por meio do confronto de ideias presentes em A Democracia na América e Cartas Mexicanas, escritas por Tocqueville na mesma época de sua viagem aos Estados Unidos, e outros escritos referentes à discursos políticos proferidos na Assembleia Francesa.

Palavras-chave: Tolerância, Democracia, Pluralismo, Acolhimento, Fragilidade.

\section{ABSTRACT}

Since the Enlightenment conception of tolerance, distrust of irrefutable certainties and acceptance of the other began to guide pluralistic and democratic social and political relations, with a view to protecting the person and promoting justice and peace. However, there is a permanent tension between claims of rights and guaranteed achievements, which is rooted in social and cultural issues associated with the notion of what is tolerable or what can be admitted as comparable, symmetrical and, therefore, respectable, despite being different. In the scope of this article, starting from a conception of religious tolerance as the origin of democratic pluralism, we want to investigate the fine line that separates the acceptable from the unacceptable, the citizen from the one who, despite being so called, cannot exercise their citizenship, his

\footnotetext{
${ }^{1}$ Doutora em filosofia e professora titular da Faculdade e Programa de Pós-Graduação em Filosofia, do Núcleo e Programa de Pós-Graduação Interdisciplinar em Direitos Humanos da Universidade Federal de Goiás. Realizou Estágio Sênior de Pós-doutorado na Universidade de Coimbra, Portugal. Estudiosa do pensamento de Jean-Jacques Rousseau e de Alexis de Tocqueville dedica-se à temas relativos à democracia e direitos humanos. É autora de diversos artigos publicados em Revistas e Livros coletivos. Traduziu artigos, organizou dossiês e livros, entre os quais "Democracia e Miséria" publicado pela Editora Almedina, em 2020. Afiliação: Universidade Federal de Goiás Lattes:http://lattes. cnpq.br/1045681574037243. ORCID:https://orcid.org/0000-0002-1367-4763 E-mail:helenaesser@ ufg.br
} 
voice is not heard, he does not participate. The discussion about the fragility of democratic pluralism will be based on the analysis of the thought of Alexis de Tocqueville. The analysis of his thinking is quite important because, having characterized democracy by the confluence of social conditions of equality and political conditions of freedom, when he visited the United States in 1830 he makes explicit, with some irony, the existence of democracy exclusively among "Anglo-Americans.". Narrating the social and political situation experienced by blacks and indigenous peoples who inhabited North America, he repudiates and denounces the exclusion and violence to which they were subjected. Although Tocqueville claims that the exclusion of blacks and indigenous peoples from North American democracy is a threat to democracy itself, his conception seems to admit integration through the assimilation of Europeandemocratic culture by blacks and indigenous peoples. The tension between "Anglo-Americans", blacks and indigenous peoples will be analyzed in order to discuss the possibility of inclusion of the other and the limits of democratic pluralism, confronting ideas present in Democracy in America and Cartas Mexicanas, written by Tocqueville in the same time of his trip to the United States, and other writings referring to political speeches given in the French Assembly.

Keywords: Political Tolerance, Democracy, Pluralism, Receptiveness, Fragility.

O grave momento vivido no Brasil e no mundo, em vista das mais diversas formas de marginalização, racismo, violência contra indígenas, negros, mulheres, LGBTQIA+, pobres, refugiados, e também em vista da crescente intimidação e violência contra pessoas que livremente manifestam suas opiniões e solidariedade a estes grupos vulnerabilizados, constitui-se como o problema mobilizador do presente artigo. Desde a concepção iluminista de tolerância, a desconfiança em relação às certezas irretorquíveis e o acolhimento do outro - como uma pessoa livre e igual - passaram a orientar relações sociais e políticas pluralistas e democráticas, tendo em vista a proteção da pessoa e a promoção da justiça e da paz. A admissão da tolerância a diferentes crenças religiosas rompe a possibilidade de identificação entre a igreja e o estado permitindo que, aos poucos, os princípios de liberdade e igualdade sejam incorporados em Declarações de Direitos, Constituições, leis, norteadores das ações de cada pessoa, de governos e instituições. Contudo, este processo de incorporação não apenas jamais se completou como se pode ver o ressurgimento das mais diversas intolerâncias.

O enfrentamento ao ressurgir de intolerâncias no cenário político mundial nos leva a discutir sobre a fragilidade da inclusão do outro diferente. Se, por um lado, as reivindicações por tolerância religiosa dos séculos XVII - XVIII estão na base de transformações sociais e políticas cuja consequência é o acolhimento de pessoas tradicionalmente excluídas - os plebeus, burgueses, trabalhadores contribuindo para democratização; por outro lado, tal inclusão não foi (tampouco é) imediata nem universal. Apesar de a Declaração dos Direitos do Homem e do Cidadão, de 1789, considerar que "os homens nascem e permanecem livres e iguais em direitos (...)”, o Tribunal Revolucionário francês não reconheceu a legitimidade da Declaração dos Direitos da Mulher e da Cidadã, determinando pena de guilhotina para sua proponente ${ }^{1}$. O exercício dos direitos políticos e civis por todas as pessoas não advém da doação generosa uns aos outros, mas depende de lutas, de conquistas, de garantias públicas.

Há uma permanente tensão entre reivindicações de direitos e conquistas garantidas que se enraíza em questões sociais e culturais associadas à noção do tolerável ou do que pode ser admitido como equiparável, simétrico e, portanto aceitável, apesar de diferente. No âmbito deste artigo, partindo de uma 
concepção de tolerância religiosa gestada no confronto entre católicos e protestantes, a inclusão do diferente vincula-se à admissão de dúvidas sobre as próprias convicções. Debilitando as próprias certezas torna-se possível conviver com o diferente, aceitar a singularidade característica de cada pessoa. Estas ideias penetram o espaço político contrapondo-se à onipotência do Estado, estabelecendo a separação dos poderes, reivindicando a participação popular nas decisões coletivas, estimulando os indivíduos a desenvolver livremente sua própria personalidade e interesses. Uma nova concepção social e política democrático-pluralista se desenvolve, a partir do final do séc. XVII, norteada pelos princípios de igualdade e liberdade que promovem a inclusão de pessoas até então excluídas.

Entretanto, a tensão permanece. Ao mesmo tempo em que surgem movimentos antiescravistas, sindicais, feministas que reivindicam o reconhecimento de suas singularidades e a garantia de direitos civis e/ou políticos, surgem também barreiras à inclusão: estudos pseudocientíficos buscam comprovar desigualdades raciais entre brancos e negros; concepções meritocráticas aplicadas à esfera política exigem comprovações de renda para o cidadão ter direito a votar e ser votado; costumes arraigados tradicionalmente mantém a tutela masculina sobre as mulheres.

O interesse do presente artigo é investigar a tênue fronteira que separa o aceitável do não aceitável; é perguntar qual o limite da democracia pluralista dos séculos XVIII-XIX. Partindo de uma breve elaboração da tolerância iluminista como origem do pluralismo democrático investigaremos, em seguida, a concepção tocquevilleana de democracia a fim de discutir a possibilidade de inclusão do outro e os limites do pluralismo político. Justifica-se a análise do pensamento de Alexis de Tocqueville por seu um autor que transita permanentemente entre dois mundos - aristocracia e democracia, liberalismo e socialismo, França e Estados Unidos - evidenciando as dificuldades dos novos tempos. Neste artigo, busca-se investigar se o pluralismo inerente à sua concepção de democracia pode admitir uma relação de respeito e integração de perspectivas de grupos culturais diferentes e quais suas consequências.

\section{TOLERÂNCIA:}

Discórdias doutrinárias e políticas, guerras religiosas fratricidas, perda de direitos civis, perseguições e torturas, ocorridas na Europa dos séculos XVI e XVII, decorrentes da cisma religiosa estão diretamente ligadas a uma concepção de tolerância como vício. A supressão da paz na comunidade cristã instigou os pensadores, já no século XVII, mas, sobretudo, no século XVIII, a reinterpretar a tolerância, que até então significava complacência ou aceitação do erro.

A perspectiva moderna de compreensão da pessoa humana como ser natural, igual às outras, dotada de razão e de liberdade pelo Criador - que lhe permite conhecer e interpretar por si mesma -, confere a cada pessoa uma potência até então desconhecida. Esta pessoa singular, indivíduo, não está naturalmente submetida a ninguém, nem a qualquer autoridade com poder de determina-la à revelia de sua razão e vontade. Entretanto, embora capaz de conhecer e julgar por si mesma, suas faculdades são 
limitadas. Não alcança o conhecimento absoluto e verdadeiro sobre todas as coisas. A consequência direta desta concepção é, em primeiro lugar, a aceitação da falibilidade como uma característica humana. Portanto, ao apresentar o verbete “Tolerância” na Encyclopedie de Diderot e D’Alembert, M. de Romilly admite que:

\begin{abstract}
Ninguém é culpado por ser limitado, e os erros do espírito não podem ser imputados a nós senão quando nosso coração aí toma parte. A essência do crime é a intenção direta de agir contra as luzes, de fazer o que se sabe que é mal, de ceder às paixões injustas, de perturbar intencionalmente as leis da ordem que nos são conhecidas; em uma palavra: toda moralidade de nossas ações está na consciência, no motivo que nos faz agir. (ROMILLY, 2010. P. 180)
\end{abstract}

O erro deixa de ser consequência do pecado, passa a ser atribuído à falibilidade inerente à condição humana, permitindo uma nova interpretação da tolerância. Esta passa a ser considerada uma virtude adequada a seres que, embora sejam "tão grandes pela sua inteligência" e "tão limitados por seus erros e paixões" (ROMILLY, 2010, p. 177) por sua natureza, estão destinados a viver uns com os outros.

A condição de agente inteligente, livre e igual, em segundo lugar, faculta a liberdade de consciência possibilitando, a cada pessoa, pensar e agir por si mesma em um espaço compartilhado. Embora a liberdade não deva ser confundida com "licenciosidade", como afirma Locke (1978b, p. 36), isso não significa propriamente um limite à liberdade, mas, como afirma Montesquieu, uma distinção entre liberdade e independência. Esta não vincula as pessoas e, portanto, não pode haver compromissos ou reciprocidade. A liberdade, por outro lado, "é o direito de fazer tudo o que as leis permitem" (MONTESQUIEU, 1979, p. 148), pois não haveria liberdade se os cidadãos pudessem fazer o que elas proíbem. Assim, a livre manifestação das opiniões e convicções individuais no espaço público, não pode prescindir do respeito às leis que zelam pela preservação de todos.

Neste sentido, a tolerância adquire uma importante dimensão política ${ }^{2}$. A liberdade de consciência e a possibilidade de cada um investigar por si mesmo os conhecimentos e crenças que recebe dos demais e da tradição, abrem a possibilidade do convívio pacífico entre diferentes e se afastam do fanatismo. A proteção à singularidade da pessoa torna-se imperativo, pois "negar a alguém o direito de pensar livremente e de agir em conformidade com os seus próprios critérios seria, a partir desta perspectiva, recusar-lhe a autenticidade da sua natureza e a integração no seio da humanidade a que, como pessoa livre, tem direito" (AURÉLIO. 1997, p. 31). A tolerância ultrapassa o âmbito pessoal da crença religiosa e se projeta no espaço político das relações entre instituições. A admissão da diversidade de crenças religiosas impede a identificação entre a igreja e o estado.

A máxima "uma fé, uma lei, um rei”, tão reivindicada pelos fanáticos religiosos, católicos e protestantes, no período das mais acirradas lutas religiosas dos séculos XVI ao XVIII, mostra-se danosa tanto para a igreja quanto para o estado. O "absurdo" dessa máxima, afirma Santos, "está no fato que de que a unidade da fé é o fundamento da lei e da unidade do poder real. Qualquer divisão religiosa, portanto, seria entendida como divisão civil, caracterizando-se como rebelião que deve ser duramente reprimida" (2006, p. 299). A confusão entre estas instituições contribui para a intolerância e para guerra, 
ao passo que a separação entre ambas pode contribuir para a moderação do fanatismo religioso e do despotismo político.

Investigando a origem das disputas religiosas que fomentaram facções, tumultos, guerras, Locke afirma que não se pode evitar a "diversidade de opiniões", por consequência foi "a recusa de tolerância para os que têm opinião diversa, (...) que deu origem à maioria das disputas e guerras que se tem manifestado no mundo cristão por causa de religião" (LOCKE, 1978a, p. 27). A defesa da diversidade de opiniões e crenças tem caráter político na medida em que entende o espaço político como um espaço plural, no qual convivem diferentes opiniões rechaçando qualquer imposição de verdade absoluta, seja de ordem religiosa ou política.

A defesa que Locke faz do direito de resistência a um governo tirânico está diretamente ligada à sua concepção de tolerância baseada no direito natural à liberdade e à segurança da pessoa. Partindo do suposto que a comunidade nunca perde o "direito natural e originário que tem de preservar-se", afirma, em consequência, o direito que as pessoas "têm não só de livrar-se dela [da tirania], mas também de impedi-la”. (LOCKE, 1978b, p. 120-121)³. Ao longo século XVIII, a noção de tolerância alastra-se nas concepções político-filosóficas republicanas e democráticas pluralistas fundadas na igualdade e na liberdade dos cidadãos, e transparecem na Declaração de Independência norte-americana de 1776 e na Declaração dos Direitos do Homem e do Cidadão de 1789.

A tirania da Coroa é uma das razões apresentadas pelos congressistas, representantes das treze colônias, para justificar a necessidade de dissolver os laços políticos que uniam as colônias norteamericanas à Inglaterra e proclamar a Independência: “a história do presente Rei da Grã-Bretanha é uma história de repetidas injúrias e usurpações, todas tendo por objetivo direto o estabelecimento de uma Tirania absoluta sobre estes Estados" (HUNT, 2009, p 220). Seus argumentos são baseados em verdades que consideram "auto evidentes"; a saber, "que todos os homens são criados iguais, dotados pelo seu criador de Direitos inalienáveis, que entre estes estão a Vida, a Liberdade e a busca da Felicidade" (HUNT. 2009, p. 219).

Os representantes do povo francês, por sua vez, "considerando que a ignorância, a negligência ou o menosprezo pelos direitos do homem são a única causa dos males públicos e da corrupção governamental" decidiram proclamar solenemente a Declaração de Direitos do Homem e do Cidadão, no curso dos eventos da Revolução Francesa. Já, no primeiro artigo, afirmam que "os homens nascem e permanecem livres e iguais em direitos" e, no segundo, que a preservação de tais direitos deve ser "o objetivo de toda associação política" (HUNT. 2009, p. 225-226). As consequências destas afirmações iniciais aprofundam-se nos demais artigos da declaração, entretanto destaco dois artigos que, mais diretamente, estabelecem a tolerância religiosa e civil em consonância com o pensamento da época. Artigo 10: "Ninguém deve ser molestado por suas opiniões, mesmo as religiosas, desde que sua manifestação não perturbe a ordem pública estabelecida pela lei”; e, artigo 11: "A livre comunicação de pensamentos e opiniões é um dos mais preciosos direitos do homem. Todo cidadão pode, portanto, falar, escrever e publicar livremente, se aceitar a responsabilidade por qualquer abuso dessa liberdade nos 
termos estabelecidos pela lei" (HUNT, 2009, p. 227). Tanto a Declaração de Independência, quanto a Declaração dos Direitos do Homem e do Cidadão revelam o espírito da época na defesa da singularidade da pessoa, no acolhimento da pluralidade de posições e na limitação do poder político.

Tolerar perde a conotação de assimetria entre o tolerante e o tolerado para tornar-se uma relação entre iguais e uma virtude pública, posto que promove a paz social em vista da aceitação da diversidade. $\mathrm{O}$ reconhecimento de que as sociedades são formadas por uma diversidade de pessoas singulares transparece no pluralismo politico, que se manifesta como liberdade de opinião, expressão e de participação, e está na origem do estado democrático moderno. Falar publicamente, expressar uma cultura, professar uma fé religiosa, defender posições políticas, integrar partidos políticos, votar em representantes sem temor e sob a proteção do estado é uma possibilidade construída pouco a pouco. Neste sentido, entre as diversas características da democracia, o pluralismo ${ }^{4}$ é uma das mais importantes, porque faculta o igual acesso de grupos sociais minoritários e/ou divergentes ao centro do debate político favorecendo a integração da diversidade.

\section{DEMOCRACIA PLURALISTA DE TOCQUEVILLE}

Apesar da diversidade de acepções e interpretações que a palavra democracia recebe na obra de Tocqueville, do nosso ponto de vista, "democracia" deve ser compreendida a partir da convergência entre um estado social marcado pela igualdade de condições e uma forma política caracterizada pela soberania do povo, no qual a inclusão social e a participação política reforçam-se mutuamente. Democracia implica um vínculo dinâmico entre condições sociais e políticas, posto que a igualdade de condições propicia que todas as pessoas possam ser reconhecidas como cidadãos e a ação política amplia e aprofunda as condições de igualdade social permitindo novas reivindicações e acolhimentos à participação.

$\mathrm{Na}$ viagem que fez aos Estados Unidos, percorrendo o país durante nove meses nos anos de 18301831, pode observar o quanto as condições sociais igualitárias penetraram o mundo político dando sentido ao dogma da soberania do povo, que estendendo-se "com toda liberdade e sem obstáculos, atinge suas últimas consequências" (TOCQUEVILLE, 1992, p. 60). A soberania do povo transparece nas leis e nos costumes, afirma Tocqueville, argumentado que a vida comunal, desde o tempo da colonização, criou o hábito da ação política que enraizou, naquele país, uma forte centralização governamental ou política e nenhuma centralização administrativa. Sendo europeu e apesar de conhecer as leis do estado Americano e perceber sua execução, admite que estranhou muito a ausência daquilo que "entre nós chamamos de governo ou administração. (...)Tudo se move a nossa volta, mas não se descobre em parte alguma o motor. A mão que dirige a máquina social oculta-se a cada instante.” (TOCQUEVILLE, 1992, p. 77).

A soberania do povo, as leis e a Constituição e a descentralização administrativa, derivam dos princípios de igualdade e liberdade sobre os quais se funda o Estado democrático tocquevilleano. Ainda que o autor não utilize a palavra pluralista ${ }^{5}$ para caracterizá-lo, os elementos sociais e políticos fundamentais desta concepção estão presentes em seu pensamento. A soberania do povo não é apenas 
uma exigência teórica ou formal. A inclusão social, que viabiliza direitos sociais, econômicos, civis e políticos a todos os cidadãos, é condição fundamental para que o exercício de cidadania seja um direito de todos os cidadãos. E, ainda que Tocqueville admita que a inclusão social seja um suposto para a cidadania, ele não autoriza a pensar que o gozo de direitos civis e políticos devam ser restritos àqueles que já ultrapassaram a condição de exclusão cívica, social e econômica, pois tais restrições implicariam a tutoria de uns sobre outros.

A participação política, mais do que um direito no estado democrático, é o meio privilegiado de realização da pessoa. Segundo Tocqueville, o espírito humano não se desenvolve senão pelo exercício da cidadania: "os sentimentos e as ideias não se renovam, o coração não cresce e o espírito não se desenvolve a não ser pela ação recíproca dos homens uns com os outros" (DA. T. II, parte 2, cap. 5, p. 623). Considerando que apenas no estado democrático a liberdade pode tornar-se um direito igual para todos, acolhimento da pluralidade de ideias e posições se faz necessário. Tensões e divergências são, portanto, próprias à convivência democrática, nenhuma identidade entre interesses, opiniões, crenças pode ser obrigatória. Neste sentido, Françoise Melonio explica que, segundo Tocqueville "a democracia não é o lugar da identidade miraculosa entre os homens, mas é o regime determinado pela relação entre classes antagônicas". (MELONIO. 1993. p. 37).

Neste cenário turbulento, Tocqueville considera que as religiões cumprem a importante tarefa de dirigir as pessoas em direção umas às outras fortalecendo seus vínculos comuns. Isso não pode significar qualquer ingerência da religião no governo, mas sobre as "almas" das pessoas. É regulando os costumes que as religiões contribuem para moderar as democracias. Independentemente da verdade intrínseca da religião, Tocqueville considera fundamental que creiam, pois as inúmeras religiões ${ }^{6}$, embora difiram no modo de cultuar a Deus, convergem acerca dos deveres recíprocos entre as pessoas.

Nos discursos e escritos políticos de Tocqueville encontramos, por um lado, a convicção de que, ao conjunto dos cidadãos, cabe zelar para que os direitos civis, sociais e políticos redundem no respeito aos princípios democráticos sobre o qual se assenta a vida pública; por outro lado, a convicção de que cabe às instituições político-jurídicas do Estado assegurar as condições sociais de igualdade para que os direitos civis, sociais e políticos não sejam mera formalidade vazia de realidade. A relação intrínseca entre os cidadãos e as instituições do Estado, que anima o pensamento e a ação de Tocqueville, sustentase em suas memórias de viagens expressas no primeiro tomo de A democracia na América.

Ao retornar para França depois de nove meses percorrendo os Estados Unidos dedicou-se a uma longa e cuidadosa análise das condições sociais, econômicas, culturais e das instituições jurídico-políticas que estruturam o Estado e a sociedade norte americanas. Evidenciou a profunda igualdade social entre os "anglo-americanos"” e como esta igualdade transparece amplamente na vida coletiva, inclusive na descentralização administrativa que estrutura a política desde o âmbito da Comuna. Após a investigação das diversas instituições e poderes dos Estados Unidos, afirma que rigorosamente é o povo quem governa, tal a sua presença constante ${ }^{8}$. É ele que elege seus representantes, determina seus mandatos, sugere suas pautas, fiscaliza a execução. 
Nesse Estado, afirma, os cidadãos tem uma espécie de interesse pessoal em que todos participem, se integrem às instituições e obedeçam às leis, pois quem compartilha de uma posição minoritária num aspecto da vida pública pode fazer parte da maioria noutro aspecto; e, se deseja o respeito dos demais a essa posição, precisa, do mesmo modo, respeitar as posições minoritárias de que não compartilha. Nas democracias não deve haver identidade entre interesses, opiniões ou crenças. Por isso a liberdade de imprensa existente nos Estados Unidos é emblemática. Se cada pessoa tem o direito de participar do governo é fundamental que possa, também, conhecer as diferentes opiniões e decidir por si mesmo sobre a posição a ser tomada. "A soberania do povo e a liberdade de imprensa são duas coisas inteiramente correlatas" (TOCQUEVILLE, 1992, p. 204). A livre circulação de ideias e opiniões no espaço público acolhe a diversidade social e às submete ao julgamento popular. É esta liberdade de pensamento e expressão que pode ser encontrada na base do respeito às leis. Tocqueville afirma ser perceptível a confiança da população na legislação que rege o país e, conclui, o povo obedece às leis "não apenas porque é obra sua, mas também porque pode alterá-la quando por acaso ela o fira" (TOCQUEVILLE, 1992, p. 276).

Tocqueville seguidamente, ao longo de A democracia na América, chama atenção à agitação existente nos Estados Unidos. Desde a sua chegada na América do Norte observa movimento, tumultos, clamores, "mil vozes" que expressam diferentes necessidades sociais ${ }^{9}$ e repercutem nas leis e no governo. A pluralidade de opiniões e ideias, assim como a participação de todos e a reciprocidade são condições necessárias para que cada um desenvolva a tolerância e o respeito às posições divergentes, que fundamentam, segundo Tocqueville, o estado democrático plural, no qual não há certezas irretorquíveis, mas possibilidades a serem construídas ${ }^{10}$.

\section{O ACOLHIMENTO DO OUTRO:}

No último capítulo do primeiro tomo de A democracia na América (Algumas considerações sobre o estado atual e futuro provável das três raças que habitam o território dos Estados Unidos), Tocqueville deixa muito claro seu repúdio à escravidão dos negros e à aniquilação dos indígenas. Ao iniciar este capítulo afirma que "encontra-se, na América, outra coisa ainda, além de uma imensa e completa democracia" (TOCQUEVILLE, 1992, p. 367). Essa outra coisa diz respeito aos "povos que vivem no Novo Mundo", os quais podem ser considerados "americanos sem ser democráticos" (TOCQUEVILLE, 1992, p. 367). Apesar de anglo-americanos, negros e indígenas encontrarem-se misturados sobre o solo americano, "a educação, a lei, a origem e até a forma exterior dos traços criaram entre eles uma barreira quase instransponível” (TOCQUEVILLE, 1992, p. 368). Estão reunidos, mas não integrados. A democracia reina entre os anglo-americanos e, "abaixo deles surgem o negro e o indígena" (TOCQUEVILLE, 1992, p. 368). A palavra abaixo é bastante descritiva da desigualdade e da opressão na qual vivem: 
Essas duas raças infelizes não tem em comum nem o nascimento, nem a fisionomia, nem a língua, nem os costumes, apenas seus infortúnios os assemelham. As duas ocupam uma posição igualmente inferior no país em que habitam; experimentam ambas os efeitos da tirania; e embora sejam diferentes suas misérias, podem acusar os mesmos autores. Não se poderia dizer, ao ver o que se passa no mundo, que o europeu é para os homens das demais raças o que o próprio homem é para os animais? Faz com que sirvam ao seu uso e, quando não os pode curvar, os destrói. (TOCQUEVILLE, 1992, p. 368)

Neste longo capítulo encontram-se inúmeras passagens que demonstram a indignação de Tocqueville. Por exemplo, quando afirma que "não foi no interesse dos negros, mas no dos brancos que a escravidão foi destruída nos Estados Unidos" (TOCQUEVILLE, 1992, p. 399). E, por isso mesmo, compreende que a abolição da escravidão reforça o preconceito e a desigualdade que "se grava nos costumes à medida que se apaga das leis". (TOCQUEVILLE, 1992, p. 399) ${ }^{11}$. Ainda que formalmente igual e livre, a desigualdade e a opressão permanecem:

Oprimido, pode se queixar, mas só encontra brancos entre seus juízes. A lei, no entanto, abre-lhe o banco dos jurados, mas o preconceito afasta-o dele. Seu filho é excluído da escola em que vai se instruir o descendente dos europeus. Nos teatros, ele não conseguiria comprar, nem a preço de ouro, o direito de sentar junto daquele que foi seu amo; nos hospitais, (...). Assim o negro é livre, mas não pode compartilhar nem os direitos, nem os prazeres, nem os trabalhos, nem as dores, nem mesmo o túmulo daquele de quem foi declarado igual; em nenhum lugar poderia encontrar-se com este, nem na vida, nem na morte. (TOCQUEVILLE. 1992, p. 398)

Convicto que de que não há democracia sem que haja equilíbrio entre condições sociais de igualdade e condições políticas de liberdade, Tocqueville, eleito pela primeira vez em 1839 para deputado da Assembleia Legislativa da França, atuou como relator da Comissão de deputados encarregada de preparar um projeto de lei para abolição da escravidão nas colônias francesas. Movido pela convicção de que a escravidão é uma violência contra a humanidade (TOCQUEVILLE, 1985, p. 42) Tocqueville propôs a "emancipação simultânea de todos os escravos" (TOCQUEVILLE, 1985, p. 49) e, considerando que não basta decretar a alforria, assume que a tarefa da Comissão é apresentar medidas práticas para erradicar a cultura da escravidão.

No que diz respeito aos indígenas, Tocqueville é igualmente enfático. Inicia o capítulo lembrando as tantas "tribos indígenas" que já haviam sido destruídas no início do século XIX. Ele e Beaumont estavam em Menphis, em dezembro de 1831, quando presenciaram a remoção dos Choctaw de seu território em vista do Indian Removal Act $^{12}$ de 1830 (que determinou a remoção de mais quatro povos: Creecks, Cherokee, Chickasaw e Seminole). Tocqueville narra sua surpresa e revolta ao ver saírem da floresta um número enorme de indígenas para embarcarem em um navio, que os levaria a outra margem do Mississipi, a fim de alcançar as terras que o governo americano lhes havia prometido:

Estávamos já no coração do inverno e o frio, naquele ano, era furiosamente severo; a neve endurecera a terra e o rio carregava blocos enormes de gelo. Os índios carregavam consigo as suas famílias; arrastavam atrás de si feridos, doentes, crianças que acabavam de nascer e velhos que iam morrer. Não tinham nem tendas, nem carros, apenas algumas provisões e armas. Os vi embarcar para atravessar o grande rio e aquele espetáculo solene jamais vai deixar a minha lembrança. Não se ouviam, no meio daquela multidão 
reunida nem soluços, nem queixas; calavam-se. Seus infortúnios eram antigos e eles sabiam irremediáveis. (TOCQUEVILLE. 1992, p. 377)

A indignação de Tocqueville, expressa em A democracia na América, não se deve apenas ao destino destes povos, mas recai fortemente sobre os ardis utilizados pelos anglo-americanos para submeter os indígenas "de maneira regular e, por assim dizer, inteiramente legal" (TOCQUEVILLE, 1992, p. P. 377). Na biografia de Tocqueville, escrita por Brogan, este afirma que a ironia do viajante assume um "tom voltairiano" ao narrar o episódio em uma carta para sua mãe:

Os americanos calcularam, disse, que um quilometro quadrado pode alimentar dez vezes mais os homens civilizados do que os selvagens ${ }^{13}$; onde quer que os civilizados se instalem, os selvagens devem ir embora: 'veja que belo tipo de lógica'. Então, os Choctaw tiveram que abandonar suas terras, onde viviam havia talvez mil anos, e, recompensados com presentes caros ('frascos de conhaque, colares de vidro, brincos e espelhos'), intimidados pela sugestão da força, tiveram de se arrastar por quase quinhentos quilômetros, sem sequer ser autorizados a aguardar pela primavera. (BROGAN, 2012, p. 204)

Neste longo capítulo final do primeiro tomo de A democracia na América, Tocqueville manifesta convictamente o respeito devido à humanidade inerente a todas as pessoas. A ação dos anglo-americanos em relação aos negros e indígenas é aviltante, humilhante. E, segue, a violência moral tem consequências políticas: em um estado democrático a desigualdade e a opressão (às quais negros e indígenas estão submetidos) tendem a destruí-lo. Preservar a democracia em solo norte-americano exige incorporar as "três raças".

\section{INTERCULTURALIDADE COMO LIMITE À PLURALIDADE:}

Em que pese Tocqueville admitir a pluralidade de perspectivas como característica da democracia, esta pluralidade parece restringir-se àquela existente entre os povos europeus e angloamericanos. Embora ele afirme - logo após sua viagem aos Estados Unidos (1831-1832) - que a exclusão de negros e indígenas da democracia naquele país é uma ameaça à própria democracia, sua concepção não parece admitir uma integração entre culturas, mas a assimilação e subordinação da cultura democráticoeuropeia pelos negros e indígenas.

A humanidade que Tocqueville reconhece em todas as pessoas, não o impede de referir-se aos indígenas como "selvagens" nem de afirmar que a escravidão "degradou" o negro. Se há uma crítica veemente à ação dos anglo-americanos no seu texto, há também a convicção de que o homem que "atrai todos os olhares, o primeiro em sabedoria, em poder, em felicidade, é o homem branco, o Europeu, $o$ homem por excelência". (TOCQUEVILLE, 1992, p. 368 - grifo nosso). Durante a viagem aos Estados Unidos, ao escrever a seu pai entusiasmado com as florestas densas do novo mundo, afirma: "A natureza fez tudo... não falta nada, senão o homem civilizado; e ele está bem à porta.” (BROGAN, 2012, p. 177 grifo nosso). Parece que Tocqueville está a insinuar que cabe a este "homem por excelência" estender a democracia amplamente no novo mundo elevando negros e indígenas à condição de "civilizados". 
Não parece que Tocqueville despreze os negros ou os indígenas, mas que se relaciona com o mundo e com as demais pessoas a partir de uma posição autocentrada. Ainda que desconheça a cultura, o modo de vida, a religião, os valores, a estrutura social e política dos povos indígenas e dos negros escravizados, está convicto que o europeu - o homem por excelência -, é culturalmente superior aos demais. Entretanto, em que pese esta concepção, Tocqueville não autoriza a opressão e a violência, mas a tutela ${ }^{14}$. Ele parte da consideração de uma menoridade ou imaturidade de alguns povos ou culturas, mas também da possibilidade de se desenvolver com o amparo, proteção, estímulos adequados. Como relator da Comissão encarregada de examinar uma proposição sobre a abolição da escravidão nas colônias francesas, quando deputado, poucos anos após seu retorno da viagem aos Estados Unidos, Tocqueville apresenta diversas medidas para integrar os ex-escravizados, como pessoas livres, à sociedade. Apesar do seu esforço para alterar a estrutura econômica, social e cultural a fim de impedir que se perpetuem as posições antagônicas de inferior e superior, de mando e obediência, as quais excluem as pessoas da participação política, as medidas propostas supõem a assimilação da cultura do homem por excelência pelos negros libertos.

Tocqueville afirma que o sequestro dos negros na África e sua mercadorização foi responsável pelo aviltamento da humanidade destas pessoas. Separados de suas origens, famílias, língua, religião, costumes, os negros escravizados são levados a compreenderem-se como propriedade de outrem. Pela violência foi feito escravo e por ela "não aprendeu senão a submeter-se e a obedecer" (TOCQUEVILLE. 1992, p. 369). Entendendo a escravidão como um grande mau moral e político, Tocqueville saúda a iniciativa de um grupo de cidadãos anglo-americanos que, em 1820, reuniu-se em uma sociedade para financiar o retorno de negros libertos para Libéria, uma nova colônia nas costas da Guiné. Retornados à África, estas pessoas retomam sua liberdade e sua dignidade e, ali reunidos, introduzem as instituições que conheceram nos Estados Unidos: "A Libéria tem um sistema representativo, jurados negros, magistrados negros, sacerdotes negros; pode-se ver templos e jornais..." (TOCQUEVILLE. 1992, p. 416417). Encerra esta ideia dizendo que até então a África estava "fechada às artes e às ciências dos brancos" (TOCQUEVILLE. 1992, p. 417), mas que fundação da Libéria poderia reverter, pois: "Os bárbaros se apropriaram das luzes da civilização no seio da servidão e aprenderam na escravidão a arte ser livres" (TOCQUEVILLE. 1992, p. 417 - grifo nosso).

É com esta perspectiva civilizatória, de fundo iluminista, que Tocqueville apresenta sua oposição à política devastadora dos anglo-americanos em relação aos negros e aos povos indígenas. Apesar das inúmeras diferenças existentes entre a condição de cada um deles nos Estados Unidos observados por Tocqueville, percebe-se a mesma indignação contra o aviltamento imposto e, também, a mesma concepção acerca da necessidade de civiliza-los.

À diferença dos espanhóis que pilharam e massacraram os povos indígenas originários, os angloamericanos os trataram como povos independentes, afirma Tocqueville. Estabeleceram relações de comércio com base em contratos que acabaram os tornando dependentes de produtos manufaturados 
sobre os quais não tinham qualquer conhecimento ou domínio. Esta situação vulnerabilizou os indígenas e permitiu aos anglo-americanos impedir o gozo dos direitos ancestrais dos indígenas e, até mesmo, extermina-los "sem violar um só dos grandes princípios da moral aos olhos do mundo" (TOCQUEVILLE, 1992, p. 393). Para além de sua revolta contra a aniquilação destes povos, Tocqueville critica os anglo-americanos porque não souberam civilizar os índios:

O grande erro dos legisladores dos Índios foi não compreender que, para conseguir civilizar um povo, é preciso primeiro conseguir que se fixe, e só seria possível fazer isso cultivando o solo; antes de tudo era preciso transformar os índios em agricultores. (TOCQUEVILLE, 1991, p. 380)

Em que pese certas características comuns entre todos os povos caçadores e nômades, Tocqueville reforça o desgosto dos indígenas norte-americanos com a civilização, algumas linhas abaixo, em vista da sua inerente preguiça. Segundo o autor, os índios consideram o trabalho não apenas "um mal, mas como uma desonra; e seu orgulho luta contra a civilização quase tão obstinadamente como a sua preguiça" (TOCQUEVILLE. 1992, p. 380). O trabalho como origem da apropriação privada ${ }^{15}$, incompreensível para os povos indígenas originários daquelas terras, era a justificativa dos angloamericanos para declararam o solo norte-americano, despido de plantações, cercas, e outras marcas que denotam trabalho humano, como disponíveis a todos aventureiros. Os povos que ocupavam aquela "vasta região", afirma Tocqueville (1992, p. 28), "não a possuíam". E segue, sentenciando o destino destes povos:

É pela agricultura que o homem se apropria do solo, e os primeiros habitantes da América do Norte viviam dos produtos da caça. Seus implacáveis preconceitos, suas paixões indomadas, seus vícios e talvez mais ainda suas selvagens virtudes, os destinavam a uma destruição inevitável. (...) A Providência, os colocando no meio das riquezas do novo mundo, parecia só lhes ter dado um curto usufruto, estavam aí apenas esperando. As costas tão bem preparadas para o comércio e a indústria, os rios tão profundos, o inesgotável vale do Mississipi, o continente inteiro parecia, então, o berço ainda vazio de uma grande civilização. (TOCQUEVILLE, 1992, p. 28 - grifo do autor)

Considerando que a população de colonos europeus era significativamente menor do que as populações indígenas, transformar os seus hábitos os tornando "civilizados" era, na verdade, uma forma de submeter estes povos tão orgulhosos de si mesmos. Em Louisiana, por exemplo, a adaptabilidade dos colonos franceses, que conviviam com inúmeros povos numericamente muito superiores a eles, tinha "natureza imperialista" (VIDAL, 2004, p. 38). Um dos protocolos diplomáticos aceitos pelos franceses para selar as alianças com os povos indígenas foi a distribuição de presentes (que nunca foi aceito pelos indígenas como retribuição por serviços prestados). Entretanto, por meio da distribuição de presentes como medalha com a esfinge do Rei de França, uniforme, chapéu - o governador francês conseguiu distinguir "chefes" subvertendo o "sistema horizontal [predominante naqueles povos], no qual dezenas, até centenas de chefes compartilhavam um poder que não era coercitivo" (VIDAL, 2004, p. 39), exercendo, portanto, o controle politico. 
Se o domínio político foi a primeira forma de fazer uma aliança vantajosa aos colonos, na medida em que estes se fixaram, cresceram e passaram a produzir os bens necessários ao seu conforto, os povos indígenas, apesar de rejeitarem o que consideravam sem utilidade para si, apreciaram uma série de objetos que facilitavam o trabalho. Pouco a pouco os produtos manufaturados dos colonos tomam o lugar dos utensílios tradicionais fabricados pelos indígenas. Contudo, afirma Vidal, "como eles eram incapazes de repará-los ou de substitui-los por si mesmos, acabam, por fim, em uma posição de dependência" (2004, p. 46). No final do séc. XVIII, o crescimento da população de colonos anglo-americanos e o aumento da produção de algodão para a indústria têxtil em desenvolvimento na Inglaterra, motiva uma série de acordos entre os anglo-americanos e os povos indígenas. Apesar destes acordos se realizarem entre povos livres e iguais, a condição dos indígenas era sempre muito mais vulnerável pressionando para que aceitassem a troca de suas terras pela paz. A situação segue se deteriorando, até que em 1830 o Congresso aprova o "Indian Removal Act", que ocasionou a remoção de Choctaw presenciada por Tocqueville, quando deslocava-se ao sul pelo rio Mississipi.

Em uma rápida incursão pelo México entre dezembro de 1831 e janeiro de 1832, durante a viagem aos Estados Unidos, relata em suas Cartas Mexicanas (escritas aos amigos e familiares durante esta breve viagem ${ }^{16}$ ) a situação de desigualdade e opressão sofrida pelos povos originários do México. Para além da pobreza, da imundice, da indolência dos habitantes, da ineficiência dos poderes públicos, afirma, "a liberdade não aparece em nenhum lado; a libertinagem, que existe em seu lugar, prejudica a todos e não faz bem a ninguém" (TOCQUEVILLE, 1999, p. 55). Tocqueville considera a situação dos mexicanos comparável com a dos franceses. A democracia em ambos os países ${ }^{17}$, afirma, "crescia abandonada aos seus instintos selvagens, como uma criança sem supervisão paterna que se exercita sozinha pelas ruas e que conhece unicamente a maldade e os vícios” (TOCQUEVILLE, 1999, p. 108).

Impressiona-se que, apesar de disfrutarem as mesmas vantagens naturais que os angloamericanos, e que tenham deliberadamente copiado a Constituição e as leis dos Estados Unidos, a República Mexicana permaneça sob um “espírito aristocrático" que inviabiliza os esforços dos colonos franceses (interesse de Tocqueville nesta rápida viagem) de se estabelecerem, produzirem e enriquecerem no México, como era possível nos pântanos da Louisiana ${ }^{18}$. As diversas cartas que Tocqueville escreveu neste momento buscam desvendar "por que fracassam os empenhos da civilização no México?" (TOCQUEVILLE, 1999, p. 64). Apesar da questão que ele mesmo formulou, a pressa de sua viagem, o desconhecimento da língua espanhola, a falta de planejamento e de organização prévia, não lhe deu oportunidade de conhecer a diversidade cultural dos povos originários, nem a situação específica da colonização espanhola no México. A resposta a esta pergunta exigiria de Tocqueville uma sensibilidade que ele não parece ter; a sensibilidade com o outro, com o diferente.

Segundo Aguilar Rivera, em vista das notas de Tocqueville sobre a América do Sul e sobre o México, 
Pode-se concluir que Tocqueville não tinha uma imagem clara do estado social real da região. Ele se concentrou quase exclusivamente no momento da fundação das sociedades, mas ignorou como a desigualdade de condições tomou conta da América Espanhola no decorrer dos séculos após a chegada dos espanhóis. Ele acreditou erroneamente que a mistura de raças tinha nivelado os costumes dos habitantes da América Espanhola. (AGUILAR RIVERA, 2004, p. 167)

A condição de selvagens ou de bárbaros impõe que estas pessoas - indígenas e negros - sejam “civilizadas" para, então, integrarem o Estado democrático. Suas culturas e suas estruturas sócio-políticas sequer são consideradas por Tocqueville. Ao discordar expressamente das teorias racistas, antidemocráticas e fatalistas de Arthur de Gobineau, que, segundo Tocqueville, considerava "os homens dos nossos tempos como se fossem crianças grandes, muito degeneradas e mal criadas" (TOCQUEVILLE, 1959, p. 280-281), afirma jamais ter imaginado que as pessoas não fossem capazes de liberdade. Entretanto, parece também jamais ter imaginado que liberdade pudesse ser gozada por um "selvagem" ou "bárbaro".

Se a democracia pluralista, capaz de integrar singularidades diversas, sustenta-se sobre o pressuposto de igualdade entre pessoas que se reconhecem e se respeitam, admitir qualquer tutela civilizatória sobre indígenas e negros, que os submete culturalmente, cria uma estrutura social e política desigual que viola a própria democracia.

\section{CONSIDERAÇÕES FINAIS}

Partimos da concepção de tolerância que se enraíza no âmbito político-democrático, por meio da igualdade e da liberdade das pessoas, como pluralismo. Em grande medida, tais ideias encontram acolhimento na concepção tocquevilleana de democracia, cujo pressuposto é a igualdade e a liberdade de manifestação e de participação dos cidadãos no espaço público. Contudo, admite Tocqueville, nos Estados Unidos que visitou em 1830, a democracia reinava exclusivamente entre os "angloamericanos". Observando a situação social e política vivida pelos negros e indígenas que habitavam a América do Norte, repudia e denuncia a exclusão e a violência às quais estavam submetidos. Ao exaltar as condições democráticas ressalta, por um lado, a situação de opressão vivida pelos indígenas e pelos negros nos Estados Unidos; entretanto, por outro lado, ao referir-se a eles como "bárbaros, selvagens, preguiçosos, degradados" revela não reconhecer as contribuições que suas culturas possam aportar à construção de um Estado democrático pluralista, aberto à integração do outro, permanentemente inacabado. Parece advogar, pelo contrário, que a integração de índios e negros à democracia dos "angloamericanos" exige que abram mão de sua cultura e assimilem uma nova, parece exigir que estas pessoas depreciem a si mesmas, a sua cultura, seus valores e, então, tornem-se o que não são.

Se Tocqueville avança no sentido de contribuir para uma democracia pluralista e participativa, parece-nos, entretanto que sua contribuição tem limites claros. Se ele denuncia a maneira como "os espanhóis estugam seus cães contra os índios como se fossem animais ferozes, pilham o Novo Mundo 
assim como uma cidade tomada de assalto, sem discernimento, nem misericórdia”; consente, também, que "o resto das populações indígenas escapadas ao massacre acabe por misturar-se aos vencedores e adote a sua religião e os seus costumes" (TOCQUEVILLE, 1999, p. 392-393). Não percebe ele, entretanto, nem a violência desta adesão, nem a resistência daqueles que - ainda hoje - mantém sua língua, costumes, tradições. No mundo contemporâneo a integração intercultural - capaz de acolhimentos múltiplos em permanente abertura e inacabamento - aparece, cada vez mais, como um espaço de resistência democrática e de construção da paz.

\section{REFERENCIAS BIBLIOGRAFICAS:}

AGUILAR RIVERA, José Antonio. Tocqueville on equality and democracy: reflections on Latin America. Tocqueville Review. vol. XXV, nº 2, 2004.

AURÉLIO, Diogo. Um fio de nada. Ensaio sobre a tolerância. Lisboa: Cosmos, 1997.

BIGNOTTO, Newton. Tolerância e diferença. In: NOVAES, Adauto (org.). Civilização e barbárie. São Paulo: Cia das Letras, 2004.

BOESCHE, Roger. The strange liberalism of Alexis de Tocqueville. Ithaca and London, Cornell University Press, 1987.

BROGAN, Hugh. Alexis de Tocqueville, o profeta da democracia. Rio de Janeiro : Record, 2012.

CARDOSO, Clodoaldo. A Tolerância e seus limites. São Paulo: UNESP, 2003.

CASSIRER, Ernest. Filosofia do iluminismo. Campinas: UNICAMP, 1992.

DECLARAÇÃO DE PRINCÍPIOS SOBRE A TOLERÂNCIA, 1995. UNESCO. Biblioteca Virtual de Direitos Humanos da USP http://www.direitoshumanos.usp.br/index.php

FETSCHER, Iring. La tolerancia. Uma pequena virtude imprescindible para la democracia. Panorama histórico y problemas actuales. Barcelona: Gedisa, 1996.

HUNT, Lynn. A invenção dos direitos humanos: uma história. São Paulo : Cia das Letras, 2009.

LEFORT, Claude. A questão da democracia. In: revolução, e liberdade. Rio de Janeiro, Paz e Terra, 1991.

LOCKE, John. Carta acerca da tolerância. São Paulo, Abril Cultural, 1978a. (Coleção Os Pensadores). Segundo Tratado sobre o Governo. São Paulo, Abril Cultural, 1978b. (Coleção Os Pensadores). MÉLONIO, Françoise. Tocqueville et les français. Paris, Aubier, 1993.

MONTESQUIEU. O espírito das leis. São Paulo, Abril Cultural, 1979. (Coleção Os Pensadores).

ROMILLY. Verbete Tolerância. (traduzido por Maria Cecília Pedreira de Almeida) In: SANTOS, Antônio Carlos (Org.). O outro como problema: o surgimento da tolerância na modernidade. São Paulo: Alameda, 2010. 
ROS. Juan Manuel. Los dilemas de la democracia liberal. Barcelona, Critica, 2001.

A via de mão dupla: Tolerância e Política em Monstesquieu. Ijuí: UNIJUÍ; Aracaju: EDUFS, 2006.

John Locke Político. A marca da tolerância. São Paulo, Loyola, 2021.

SANTOS, Boaventura de Souza. Por uma concepção multicultural dos direitos humanos. Lua Nova, $\mathrm{n}^{\circ}$ 39, 1997.

TOCQUEVILLE, Alexis de. De la democratie en Amerique. In: Oeuvres. T. II. Paris: Gallimard, 1992. (Bibliothèque de la Pléiade).

Écrits et discours politiques. In : Oeuvres Complètes. Tomo III, vol. 1. Paris : Gallimard, 1985.

. Correspondence d' Alexis de Tocqueville et Arthur de Gobineau. In: Oeuvres Complètes. T. IX, Paris: Gallimard, 1959.

Cartas mexicanas. In. AGUILAR RIVERA, José Antônio (Org.). México, Cal y Arena, 1999.

VIDAL, Cécile. De l'incorporations à la exclusion. Les realtions entre amérindiens, européens et angloamericains dans la valée du Mississippi de 1699 a 1830. La Revue Tocqueville. Vol. XXV, nº 2, 2004.

VOLTAIRE. Tratado sobre a tolerância. São Paulo: Martins Fontes, 1993.

WOLFF, Francis. Quem é bárbaro? In: NOVAES, A. (org.) Civilização e barbárie. São Paulo, Cia das Letras, 2004.

\section{Trabalho recebido em 01 de julho de 2021 Aceito em 02 de novembro de 2021}

\footnotetext{
${ }^{1}$ Marie Gouze, autora da declaração, nasceu em uma família burguesa em 1748, casou-se com um general mais velho com quem teve um filho e enviuvou poucos anos depois. Bem educada, frequentou salões de literatura em Paris e, sob o pseudônimo Olympe de Gouges, escreveu obras de teatro manifestamente anti-escravistas e abolicionistas, publicou folhetos políticos, propôs reformas sociais, apoiou ideias republicanas e feministas, como, por exemplo, o direito de a mulher votar. Em 1791 publicou a Declaração dos Direitos da Mulher e da Cidadã.

${ }^{2}$ Para maior aprofundamento sobre o vínculo entre tolerância religiosa e política sugiro: FETSCHER. A Tolerância. Barcelona, Gedisa, 1996; CARDOSO, A Tolerância e seus limites. São Paulo: UNESP, 2003; SANTOS, John Locke Político, a marca da tolerância. São Paulo, Loyola, 2021. A noção de tolerância tem origem religiosa e, a partir desta, conforma a cultura e penetra o âmbito social e político, entretanto os limites do presente artigo não permitem melhor desenvolver esta relação de modo que optamos por circunscrever a análise do conceito mais diretamente ao âmbito político.

3 No Segundo Tratado sobre o Governo, no cap. XIX: Da dissolução do Governo, Locke expõe cuidadosamente argumentos consistentes sobre o direito à resistência contra governos usurpadores e tirânicos, na medida em que reconhece nestes governos a violação dos direitos naturais e da finalidade do estado civil. Neste sentido, reproduzo aqui, integralmente, o parágrafo 220 de onde extrai as frases citadas no texto: "Nestes e em outros casos semelhantes, quando se dissolve o governo, o povo fica em liberdade de prover para si, instituindo novo legislativo, que difira do anterior pela mudança das pessoas ou da forma, ou por ambas as maneiras, conforme julgar mais conveniente ao próprio bem e segurança; porque a sociedade não pode nunca, em virtude da culpa de outrem, perder o direito natural e originário que tem de preservar-se, o que somente pode conseguir estabelecendo um poder legislativo, e pela execução adequada e imparcial das leis por ele feitas. Mas a situação dos homens é tão miserável
} 
que eles não são capazes de fazer uso desse remédio senão quando já é muito tarde para curar qualquer um. Dizer ao povo que poder prover para si mesmo instituindo outro legislativo quando o antigo desapareceu devido à opressão, artifício ou transferência a um poder estranho, importa somente em dizer-lhe que pode esperar desafogo quando é muito tarde e o mal já não tem cura. Com efeito, equivale a ordenar-lhe que seja escravo para depois cuidar da liberdade; e, vendo-o acorrentado, dizer-lhe para agir como se estivesse livre. Fazê-lo é mais zombaria do que desafogo, se a tal se chagasse; e os homens não poderão jamais estar seguros contra a tirania se não houver qualquer meio de escapar-lhe até que estejam inteiramente a ela submetidos; e, por conseguinte, é por isso que tem não só o direito de livrar-se dela mas também de impedi-la." (p. 120-121)

${ }^{4}$ É importante destacar que, segundo a Constituição brasileira de 1988, o pluralismo político é um dos princípios fundamentais da República Federativa do Brasil: Art. $1^{\circ}$ A República Federativa do Brasil, formada pela união indissolúvel dos Estados e Municípios e do Distrito Federal, constitui-se em Estado Democrático de Direito e tem como fundamentos: I. A soberania; II. A cidadania; III. A dignidade da pessoa humana; IV. Os valores sociais do trabalho e da livre iniciativa; V - o pluralismo político. Parágrafo único: "Todo o poder emana do povo, que o exerce por meio de representantes eleitos ou diretamente, nos termos desta Constituição". (grifo nosso)

${ }^{5}$ Norberto Bobbio, quando apresenta o verbete "Pluralismo democrático" no seu Dicionário de Política, afirma que Tocqueville escreveu "célebres páginas" sobre as associações, onde se desenvolvia o espírito de igualdade e de liberdade dos anglo-americanos, inspirando o pensamento pluralista. Cito: "Embora hoje, sob o nome de "Pluralismo democrático", entendam vários escritores de ciência política americanos como a teoria que se opõe ao elitismo, isso é, a teoria que, mesmo admitindo a existência de elites de poder, sustenta que, na sociedade americana, existem diversas elites em concorrência entre si, o sentido predominante e ideologicamente mais completo de "Pluralismo" é ainda o de Tocqueville" (BOBBIO, N. Pluralismo. In: BOBBIO, MATTEUCCI, PASQUINO. Dicionário de Política. Brasília, UnB, $11^{\text {a }}$ ed, 1998, p. 941)

${ }^{6}$ Segundo Tocqueville, "existe nos Estados Unidos uma multidão inumerável de seitas. Todas diferem no culto que é devido ao Criador, mas todas concordam sobre os deveres dos homens uns para com os outros. Cada seita adora a Deus à sua maneira, mas todas as seitas pregam a mesma moral em nome de Deus." (TOCQUEVILLE, 1992, p. 335-336)

${ }^{7}$ Em A Democracia na América, Tocqueville utiliza, quase sempre, a expressão "anglo-americano", ao se referir às pessoas que vivem no estado social e político democrático. Esta forma de expressão denota claramente sua percepção acerca da condição de exclusão dos negros e indígenas deste estado democrático.

${ }^{8}$ No capítulo sobre "Como se pode dizer rigorosamente que, nos Estados Unidos, é o povo que governa" (De la démocratie em Amerique. T. I, parte 2, cap. 1), Tocqueville afirma: "Não somente as instituições são democráticas em seu princípio, mas também em seu desenvolvimento; assim o povo nomeia diretamente seus representantes, e escolhe em geral todos os anos, a fim de tê-los mais completamente em sua dependência. É realmente o povo que dirige e, embora a forma de governo seja representativa, é evidente que as opiniões, os preconceitos, os interesses e mesmo as paixões do povo não podem encontrar obstáculos duráveis que os impeçam de agir no direcionamento cotidiano da sociedade" (grifos do autor)

${ }^{9}$ Tocqueville ressalta, por outro lado, que uma opinião majoritária tenda a impor-se sobre as posições minoritárias de modo a aniquilar a "independência de espírito". Na América, afirma, "enquanto se está em dúvida, fala-se, mas desde que se pronuncie irrevogavelmente, cada um se cala; amigos e inimigos parecem então ligar-se em comum acordo. [...] a maioria é revestida de uma força material e moral, que age tanto sobre a vontade quanto sobre as ações, e que impede ao mesmo tempo o ato e o desejo de praticá-lo" (TOCQUEVILLE. De la démocratie em Amerique. T. I, parte 2, cap. 7, p. 292).

${ }^{10}$ Para maior aprofundamento deste tema, sugiro a leitura do artigo: A questão da democracia, de Claude Lefort, no qual retoma o pensamento tocquevilleano para contrapor ao fenômeno totalitário (caracterizado pela unidade entre as esferas da lei, do poder e do saber) a dissolução dos marcos de referência da certeza pela democracia. (LEFORT. Pensando o Político. Ensaios sobre democracia, revolução, e liberdade. Rio de Janeiro, Paz e Terra, 1991.)

${ }^{11}$ É preciso lembrar que Alexis de Tocqueville visitou os Estados Unidos, em companhia de Gustave de Beaumont, no período compreendido entre 9 de maio de 1831 e 20 de fevereiro de 1832. Neste momento, embora a "importação" de pessoas escravizadas já estivesse proibida desde 1808, o comércio interno cresceu e na maioria dos estados do sul da costa leste a escravidão permanecia legal. A abolição da escravidão em todo território dos Estados Unidos data de 1865, com a aprovação da décima terceira emenda à Constituição dos Estados Unidos.

${ }^{12} \mathrm{O}$ Indian Removal Act refere-se à lei federal de 1830 que legalizou a remoção de cinco povos indígenas de seu território original, ao sul e sudeste do país, para que a colonização "anglo-americana" pudesse avançar. Estes povos foram deslocados para oeste do vale do Mississipi, em condições terríveis que ocasionaram enormes sofrimentos e morte da população e ficou conhecido como "trilha das lágrimas".

${ }^{13}$ Destaca-se a semelhança desta concepção com o Segundo Tratado sobre o Governo de John Locke, onde se lê: “...As provisões que servem para o sustento da vida humana produzidas em um acre de terra fechada e cultivada falando mui conservadoramente - são dez vezes mais do que pode produzir um acre de terreno de igual fertilidade aberto e em comum. Portanto, aquele que cerca um pedaço de terra e tem maior volume de conveniências da vida 
retirado de dez acres do que poderia ter de cem abandonados à natureza, pode dizer-se verdadeiramente que dá noventa acres aos homens. (...) porquanto pergunto se nas florestas selvagens, ou nos desertos incultos da América, abandonados à natureza, sem qualquer melhoramento, lavra ou cultura, mil acres produzem para os habitantes necessitados e miseráveis tantas conveniências de vida como dez acres de terra igualmente fértil do Devonshire, onde são bem cultivada." (LOCKE, 1978b, p. 49).

14 Embora Tocqueville reconheça grande diferença entre a ação dos espanhóis (a quem considera autores de "monstruosidades sem precedentes") e dos anglo-americanos (cuja ação ocorreu "sem violar um só dos grandes princípios morais aos olhos do mundo") na maneira de tratar os indígenas, reconhece violência e violação em ambas as atitudes. Ele repudia a ambas as formas de destruição dos indígenas e dos negros. Trata-se, antes, de guia-los, dirigi-los de modo que possam alcançar as condições da civilização. (Veja: TOCQUEVILLE. De la démocratie em Amerique. T. I, parte 2, cap. 10, p. 393).

${ }^{15}$ Sugiro leitura do capítulo V do Segundo Tratado sobre o Governo de John Locke.

16 Estas cartas ficaram desconhecidas por longo tempo, apenas entre final de 1980 - início de 1990, quando a Universidade de Yale (nos Estados Unidos), que tem a guarda dos manuscritos de Tocqueville, ampliou a sessão de livros raros e manuscritos, foi encontrado um arquivo com cartas, notas, esboços relativos aos seus trabalhos sobre os Estados Unidos, entre os quais "Notas sobre o México". Na verdade, estas notas descobertas explicam o enigma do "sumiço" de Tocqueville no período de sua viagem ao México. Acreditava-se até então que ele estivesse doente no período, mas não havia nenhum relato desta provável doença em suas cartas ou caderno de notas. Os manuscritos "Notas sobre o México" foram entregues a José Antonio Aguilar Rivera, que conseguiu organizá-los e publicou, pela Editora Cal y Arena, em 1999, no México.

${ }^{17}$ Em 1810 o padre José Hidalgo y Costilla declarou independência do México em relação à coroa espanhola, contudo inúmeras batalhas e revoltas foram travadas até ser reconhecida em 1821, por meio do Tratado de Córdoba, assinado pelo General "crioulo" Agustín de Ituribe e representantes da coroa. Imediatamente Ituribe proclamou-se Imperador provando novas revoltas e sua deposição em 1823, quando se estabeleceu os Estados Unidos Mexicanos. Em 1824, uma Constituição da República foi elaborada com base na Constituição dos Estados Unidos da América. Todo este período é marcado por grande instabilidade política, social e econômica, que impactou Tocqueville nos poucos dias de sua permanência.

${ }^{18}$ Em que pese a grande capacidade analítica de Tocqueville, ele errou feio ao assemelhar as vantagens naturais existentes na Louisiana e no México. Veja, por exemplo, VIDAL, Cécile. De l'íncorporations à la exclusion. Les realtions entre amérindiens, européens et anglo-americains dans la valée du Mississippi de 1699 a 1830. La Revue Tocqueville. Vol. XXV, nº 2, 2004. 